\title{
Efektivitas Pelaksanaan Ibadah Daring Ditinjau dari Roma 12:1-2
}

\author{
Dicky Dominggus \\ Sekolah Tinggi Teologi Injil Bhakti Caraka, Batam \\ Dicky.dominggus@sttibc.ac.id
}

\begin{abstract}
In 2020, the implementation of worship has changed the way from physical gathering to online worship. This is certainly a challenge for churches that are accustomed to direct worship and must get used to it. From the Bible, the text of Romans 12: 1-2 is the biblical foundation for worship. This article aims to look at the effectiveness of online worship based on Romans 12: 1-2. The method used in this research is a qualitative method with a grammatical-historical approach. Based on the research conducted, worship actually talks about everyday life. Regarding online worship, online worship is a way to fellowship with God. Because online worship has the same essence as worship for physical gatherings, it is necessary to be serious in carrying out worship online.
\end{abstract}

Keywords: Service; Online Service; Romans 12:1-2

\begin{abstract}
Abstrak
Pada tahun 2020, pelaksanaan ibadah mengalami perubahan cara dari ibadah pertemuan fisik menjadi ibadah daring. Hal ini tentunya menjadi tantangan bagi gereja yang sudah terbiasa melakukan ibadah secara langsung dan harus membiasakan diri. Dari Alkitab, teks Roma 12:1-2 landasan alkitabiah tentang ibadah. Artikel ini bertujuan melihat efektifitas pelaksanaan ibadah daring berdasarkan Roma12:1-2. Metode yang digunakan dalam penelitian ini adalah metode kualitatif dengan pendekatan historikal gramatikal. Berdasarkan penelitian yang dilakukan, ibadah sesungguhnya berbicara tentang kehidupan sehari-hari. Terkait dengan ibadah daring, pelaksanaan ibadah daring merupakan salah satu cara untuk bersekutu dengan Tuhan. Karena ibadah daring memiliki esensi yang sama seperti ibadah pertemuan fisik maka perlu adanya keseriusan dalam melaksanakan ibadah daring.
\end{abstract}

Kata Kunci: Ibadah; Ibadah Daring, Roma12:1-2. 


\section{PENDAHULUAN}

Pada awal tahun 2020, dunia menghadapi pandemi covid-19 yang berdampak pada pada semua bidang. Berbagai pihak mulai dari global, nasional hingga lokal mengambil kebijakan untuk menerapkan social dan physical distancing. Pemerintah pusat Indonesia memberikan himbauan untuk mengurangi aktifitas di luar rumah. Joko Widodo mendorong masyarakat untuk bekerja, belajar dan beribadah dari rumah. ${ }^{1}$ Hal yang sama dilakukan oleh Persekutuan Gereja Indonesia (PGI) yang mendorong gereja untuk menerapkan ibadah secara daring. ${ }^{2}$ Pelaksanaan ibadah daring sebagai bentuk pembatasan mobilitas manusia dalam berkumpul. PGI menghimbau agar warga gereja membatasi pertemuan yang tidak terlalu penting dan mengarahkan untuk memanfaatkan teknologi digital dan mengembangkan $e$-church.

Himbauan PGI terkait pelaksanaan ibadah daring mendapat respon pro dan kontra. Pihak pro

1 “Jokowi: Saatnya Kerja Dari Rumah, Belajar Dari Rumah, Ibadah Di Rumah Halaman 2 - Kompas.Com," accessed July 26, 2020, https://nasional.kopmpas.com/read/2020/03/15/14 232961/jokowi-saatnya-kerja-dari-rumah-belajardari-rumah-ibadah-di-rumah?page $=2$.

2 "PGI Dukung Ibadah Online Untuk Mengatasi Penyebaran Covid-19 - Website PGI," accessed July 27, 2020, https://pgi.or.id/pgidukung-ibadah-daring-untuk-mengatasipenyebaran-covid-19/. menyatakan bahwa ibadah daring sebagai bentuk tindakan iman dalam menangani covid-19. Pihak ini mempercayai bahwa iman yang tepat akan hadir dalam setiap upaya sederhana demi merawat kehidupan. $^{3} \quad$ Pihak yang kontra menyatakan bahwa ibadah daring sebagai tanda kurang percaya akan perlindungan Tuhan. Pihak ini memakai Mazmur 91 sebagai beriman kepada perlindungan Allah. Terlepas dari pihak pro dan kontra, PGI mendorong warga gereja untuk mengikuti protokoler pemerintah dalam upaya menangani covid-19.

Awal mulanya, ibadah tidak ada kaitannya dengan upacara agama seperti pada masa sekarang. Ibadah lebih mengarah kepada tindakan penghormatan manusia kepada Allah. Di dalam Perjanjian Lama, kata ibadah diambil dari bahasa Ibrani Shachah yang kemudian diterjemahkan menjadi worship yang berarti sujud menyembah. ${ }^{4}$ Di dalam Perjanjian Baru, ibadah berasal dari bahasa Yunani Proskuneo yang memiliki arti mencium tangan atau merendahkan diri kepada orang lain karena rasa hormat. ${ }^{5}$ Definisi dari Perjanjian Lama

\footnotetext{
3 "Pro-Kontra Ibadah Online - Bahana Online," accessed July 27, 2020, http://ebahana.com/serba-serbi/artikel/pro-kontraibadah-daring/.

4 Debora Nugrahenny Christimoty, "Teologi Ibadah Dan Kualitas Penyelenggaraaan Ibadah: Sebuah Pengantar," Pasca: Jurnal Teologi dan Pendidikan Agama Kristen 15, no. 1 (2019): 2. ${ }^{5}$ Ibid
} 
dan Perjanjian Baru menunjukkan bahwa ibadah merupakan tindakan penghormatan manusia kepada Allah. Pemahaman yang sangat berbeda dengan pada masa sekarang ini.

Di dalam pelaksanaannya, ibadah baik di dalam Perjanjian Lama dan Perjanjian baru dilaksanakan secara individu dan komunal. Ibadah pribadi dilakukan ketika seseorang berjumpa dengan Tuhan yang diekspresikan dengan tindakan nyata seperti membangun mezbah dan mempersembahkan korban. Ibadah komunal dilakukan dalam kemah pertemuan, sinagoge dan di rumah jemaat. Kedua pelaksanaan ini masih dilakukan hingga saat ini di mana ibadah dilakukan secara pribadi dalam doa pribadi dan saat teduh. Ibadah komunal dilakukan dalam berbagai bentuk ibadah seperti ibadah minggu, ibadah pemuda, sekolah minggu, ibadah komsel dan lainnya. Terlepas dari semua pelaksanaan ibadah yang dilakukan, orang percaya harus memiliki pemahaman yang benar tentang ibadah. Siringo-ringo menuliskan bahwa pemahaman yang benar terhadap ibadah akan membawa kepada ketinggian penyembahan. ${ }^{6}$ Dalam tulisannya, Chan

6 Elfrida Siringo-ringo, "Pemahaman Ibadah Sejati Berdasarkan Roma12:1-2 Terhadap Pertumbuhan Kerohanian Remaja GPPS Maranata Diski: Studi Eskesegetis," PROVEDENSI : Jurnal Pendidikan dan Teologi sedang menjelaskan bahwa pemahaman yang benar terhadap ibadah akan membawa orang percaya berjumpa dengan Allah dalam hadiratNya.

Di dalam Alkitab ada beberapa teks yang membahas tentang ibadah dan salah satunya adalah Roma12:1-2. Di dalam teks ini, Paulus menuliskan ibadah sebagai upaya mempersembahkan hidup yang berkenan kepada Allah. Dwiraharjo menuliskan Paulus menuliskan teks ini sebagai penerapan sehari-hari dari ajaran yang ia tuliskan pada bagian sebelumnya (Roma1-11). ${ }^{7}$ Artinya, pada pada pasal 111 Paulus menjelaskan pembenaran oleh iman dan pada ayat 12 sampai pasal berikutnya Paulus sedang menegaskan bagaimana perilaku sehari-hari dari orang beriman yang telah dibenarkan oleh Allah.

Hal senada dituliskan Arnold Manurung dalam tulisannya, Paulus sedang mendorong pembaca untuk menyerahkan seluruh hidup sebagai persembahan yang hidup (dihidupkan oleh Roh Kudus, yang sebelumnya mati oleh dosa). ${ }^{8}$ Persembahan yang hidup

1, no. 1 (2018): 27-51

7 Susanto Dwiraharjo, "Konstruksi Teologis Gereja Digital: Sebuah Refleksi Biblis Ibadah Daring Di Masa Pandemi Covid-19," EPIGRAPHE: Jurnal Teologi dan Pelayanan Kristiani 4, no. 1 (2020): 1

8 Arnold Manurung, "Makna Frasa 'Ibadahmu Yang Sejati' Menurut Roma12:1-2," KERUGMA: Jurnal Teologi dan Pendidikan 
dapat dilihat dari perubahan hidup dari ke hari untuk menjalani hidup kudus dan tidak berkompromi dengan dosa.

Jika ibadah di dalam Roma12:1-2 berbicara perubahan hidup orang percaya, apakah sumbangsihnya dalam pelaksanaan ibadah daring? Bagaimana tinjauan teologis teks Roma 12:1-2 terhadap efektifitas pelaksanaan ibadah daring. Melalui penelitian ini, penulis akan meninjau efektifitas pelaksanaan ibadah daring berdasarkan teks Roma12:1-2.

\section{METODE PENELITIAN}

Penelitian ini merupakan penelitian kualitatif dengan menggunakan metode deskriptif pada teks Roma 12:1-2. Analisa dalam penelitian ini menggunakan historikal gramatikal yang berguna untuk mencari makna mula-mula dari teks Roma 12:1-2 dan juga sebagai upaya untuk meninjau efektifitas pelaksanaan ibadah daring pada masa kini.

Penelitian ini dilakukan dengan dua tahapan. Pertama, meneliti makna mula-mula dari teks Roma12:1-2. Kedua, melakukan peninjauan terhadap efektifitas pelaksanaan ibadah daring berdasarkan teks Roma12:1-2.

Agama Kristen 1, no. 2 (, 2019): 105.

\section{HASIL DAN PEMBAHASAN}

\section{Ibadah Menurut Roma12:1-2}

Mempersembahkan Tubuh

Paulus mengawali ayat 1 dengan frasa demi kemurahan Allah dalam

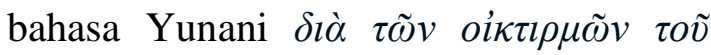
$\Theta \varepsilon o \tilde{v}$ (dia ton oiktirmon tou Theou) yang berarti dorongan atau nasihat. Kata kemurahan dalam bahasa Yunani oiktirmoun digunakan sebagai ekspresi keprihatinan terhadap orang lain dengan maksud menunjukkan kebaikan. ${ }^{9}$ Di dalam Perjanjian Baru, kata kemurahan memiliki bentuk jamak. Manurung berpendapat bentuk jamak dari kata kemurahan menunjukkan belas kasihan Allah atau kebaikan hati Allah yang berlimpah kepada orang percaya. $^{10}$ George R Knight melihat kemurahan Allah sebagai ungkapan hati Allah kepada orang percaya. Baginya, kemurahan Allah merupakan kerinduan Allah supaya orang percaya hidup dalam kasih dan kemurahannya. ${ }^{11}$ Pardomuan Marbun melihat kemurahan Allah dari kasih Allah dalam menyelamatkan manusia dari dosa. Menurut Marbun,

\footnotetext{
${ }^{9}$ Johannes E Louw dan Eugene A Nida, Greek English Lexicon of The New Testament (New York: United Bible Societes, 1989).

${ }^{10}$ Manurung, "Makna Frasa 'Ibadahmu Yang Sejati’ Menurut Roma12:1-2.”, 95.

${ }^{11}$ George R Knight, Exploring Romans: Devotional Commentary (Maryland: Review and Herald Publishing, 2010), 571.
} 
Allah membuat perjanjian untuk mengikat diriNya dengan manusia yang berdosa, namun dalam kasih-Nya ia harus menyelamatkan manusia dari dosa. ${ }^{12}$ Pendapat Manurung, Knight dan Marbun memberikan indikasi bahwa kemurahan Allah dapat dilihat dari dua sisi yakni sifat kemurahan itu sendiri yang berlimpah dan keinginan Allah untuk orang percaya hidup didalamnya. Dengan demikian, Paulus menuliskan frasa demi kemurahan Allah untuk menunjukkan belas kasihan Allah yang berlimpah dan mendorong orang percaya untuk hidup dalam kemurahan Allah dengan ditunjukkan dalam kehidupan sehari-hari.

Pada bagian berikutnya, Paulus menasihatkan jemaat dengan bahasa Yunani parakaleo dalam bentuk present indikatif aktif. ${ }^{13}$ Paulus memakai kata ini sebagai usaha ia menasihatkan jemaat untuk mempersembahkan hidup. FF bruce menuliskan Paulus menuliskan bagian ini sebagai pendahuluan dari nasihat etis kepada jemaat. ${ }^{14}$ David G Peterson berpendapat bahwa nasihat

12 Pardomuan Marbun, "Konsep Dosa Dalam Perjanjian Lama Dan Hubungannya Dengan Konsep Perjanjian," CARAKA: Jurnal Teologi Biblika dan Praktika 1, no. 1 (2020): 13.

${ }^{13} \mathrm{~J}$ W Wenham, Bahasa Yunani Koine (Malang: SAAT, 1987), 3.

${ }^{14}$ F F. Bruce, Romans: Tyndale New Testament Commentaries (Nottingham: InterVarsity, 2008), 435.
Paulus merupakan dorongan kepada jemaat untuk mengingat kasih dan kebaikan Allah di sepanjang kehidupan mereka. ${ }^{15}$ Pendapat Bruce dan Peterson menunjukkan bahwa nasihat Paulus merupakan dorongan kepada jemaat untuk mencerminkan kehidupan seperti orang-orang yang telah menerima kemurahan Allah.

$\begin{array}{ccr}\text { Dalam nasihatnya, } & \text { Paulus } \\ \text { mendorong jemaat } & \text { untuk } \\ \text { mempersembahkan tubuh } & \text { sebagai } \\ \text { persembahan yang } & \text { hidup } & \text { Paulus }\end{array}$
memakai parafrasa di atas dari bahasa Yunani $\pi \alpha \rho \alpha \sigma \tau \tilde{\eta} \sigma \alpha l \quad \tau \dot{\alpha} \quad \sigma \omega ́ \mu \alpha \tau \alpha \quad \dot{v} \mu \tilde{\omega} v$

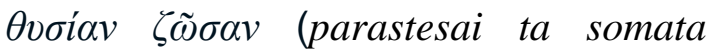
hymon tysian zosan. William Sanday menuliskan Paulus menuliskan bagian ini seperti pengorbanan pada waktu sebelumnya yang bersih dan tanpa cacat. $^{16}$ Dari pandangan Sanday dapat dilihat akan pentingnya kesempurnaan pengorbanan yang dilakukan. Hal serupa dengan John Murray yang melihat mempersembahkan tubuh adalah memberikan hidup yang kudus kepada Allah. ${ }^{17}$ Dari kedua pendapat yang ada,

15 David G Peterson, Biblical Theology For Christian Proclamation: Commentary on Romans (Nashvile: B\&H Publishing Group, 2017), 651

16 William Sanday, Romans (International Critical Commentary) (Grand Rapids Michigan: Zondervan, 2014), 576.

17 John Murray, The Epistle to the Romans, Vol 2 Chapters 9 to 16 (Grand Rapids 
dapat disimpulkan mempersembahkan tubuh merupakan memberikan hidup yang kudus, bersih dan tanpa dosa kepada Allah. Pendapat berbeda dituliskan Everet Harrison yang melihat mempersembahkan tubuh sebagai upaya menghadirkan Tuhan dalam kehidupan. Menurutnya, ketika manusia mempersembahkan tubuh maka harus berkomitmen meninggalkan dosa dari kehidupan lama. ${ }^{18}$ Dari pandangannya, Harrison menitikberatkan kepada kewajiban dari mempersembahkan tubuh itu sendiri.

Nasihat Paulus tidak hanya sampai di mempersembahkan tubuh, tetapi juga kepada sifat persembahan itu sendiri. Paulus menuliskan kata sifat hidup, kudus dan berkenan kepada Allah. Leander E Keck menuliskan ketiga sifat persembahan ini dapat dilihat dalam kehidupan sehari-hari. Baginya, bila persembahan yang dilakukan manusia memenuhi tiga kriteria yang ada maka dapat menjadi persembahan hidup yang menyenangkan hati Allah. ${ }^{19}$ Hal senada diutarakan John D Harvey yang memandang tiga kriteria yang ada

Michigan: Williams B. Eerdmans Publshing Company, 2009), 279.

18 Robert K. Rapa Everett F. Harrison,

Donald A. Hagner, “The Expositor's Bible Commentary: Romans -Galatians (Grand Rapids Michigan: Zondervan, 2008), 632.

19 Leander. E Keck, Romans: Abindon New Tettament Commentaries (Nashvile: Abingdon Press, 2005), 622. sebagai indikator dari persembahan diterima oleh Allah. ${ }^{20}$ Pandangan Keck dan harvey menilai tiga kriteria di atas merupakan filter untuk menjadi persembahan yang menyenangkan hati Allah. Hal ini dapat menjadi petunjuk bagi manusia untuk melakukan persembahan hidup yang berkenan kepada Allah.

Paulus menutup ayat 1 dengan kesimpulan dari bagian sebelumnya. Ia menuliskan tiga kriteria dari persembahan hidup merupakan ibadah yang sejati. James D. G Dunn menuliskan bahwa bagian akhir dari ayat 1 merupakan konsep Paulus tentang ibadah bukan hanya dalam pemahaman dan pikiran, melainkan dalam kehidupan sehari-hari. ${ }^{21}$ Pandangan Dunn menunjukkan bahwa ibadah bukan hanya sekadar pemahaman konseptual, melainkan penerapan aplikatif dalam kehidupan sehari-hari. F. F Bruce juga menuliskan bahwa kehidupan merupakan satu-satunya respon yang masuk akal terhadap kemurahan Allah. ${ }^{22}$ Dari pendapat Bruce dapat dilihat kehidupan orang percaya merupakan bentuk respon terbaik atas kemurahan Allah. Timothy Keller

${ }^{20}$ John D Harvey, Romans (Exegetical Guide to the Greek New Testament) 2 (Nashvile: B\&H Publishing Group, 2017), 1051.

21 James D.G Dunn, Word Biblical Commentary, Volume 38B: Romans 9-16, (Grand Rapids Michigan: Zondervan, 1988), 817.

22 Bruce, Romans: Tyndale New Testament Commentaries, 435. 
menuliskan mempersembahkan hidup kepada Allah merupakan respon mutlak terhadap kemurahan Allah. ${ }^{23}$ Pandangan Keller didasari oleh konsep orang percaya terhadap ibadah masih sebatas pemahaman. Karena itu, kehidupan sehari-hari menjadi penyeimbang dalam meresponi kemurahan Allah. Artinya, kemurahan Allah tidak hanya ditanggapi secara konseptual namun juga tindakan nyata dalam kehidupan sehari-hari.

Di dalam kehidupan masa pandemi, mempersembahkan tubuh dapat dipahami sebagai hidup takut akan Tuhan di tengah situasi yang sulit. Dalam keadaan sulit, manusia dihadapkan dua pilihan yakni hidup semakin dekat Tuhan atau sebaliknya. Manurung menuliskan mempersembahkan tubuh memiliki arti mengabdikan hidup sepenuhnya tanpa dibatasi waktu dan terjadi dalam kehidupan sehari-hari kepada Tuhan dan sesama. $^{24}$

\section{Pembaharuan Akal Budi}

Pada bagian ini, Paulus memulainya dengan larangan untuk tidak menjadi serupa dengan dunia. John D

23 Thimothy Keller, "Romans 8-16 for You" (Epsom: The Good Book Company, 2014), 181.

${ }^{24}$ Manurung, "Makna Frasa 'Ibadahmu Yang Sejati’ Menurut Roma 12:1-2.”: 105
Harvey menuliskan Paulus memakai kata larangan sebagai pendahuluan dari nasihat di ayat sebelumnya. ${ }^{25}$ Pandangan Harvey menunjukkan bahwa larangan yang dituliskan Paulus di ayat 2 memiliki hubungan dengan mempersembahkan tubuh pada ayat sebelumnya.

Paulus menuliskan frasa jangan serupa dengan dunia. Kata serupa yang dipakai Paulus berasal dari bahasa Yunani syschematizesthe dalam bentuk imperative yang merupakan perintah dan dilakukan terus menerus. ${ }^{26}$ Dengan demikian, Paulus menasihati jemaat Roma untuk terus menerus tidak serupa dengan dunia. William Barclay melihat bahwa nasihat Paulus sebagai dorongan kepada jemaat untuk tidak hidup sesuai dengan kebiasaan-kebiasaan dunia. ${ }^{27}$ Pernyataan Barclay menunjukkan bahwa kehidupan orang percaya harus dapat menentukan sikap mengikuti kehendak Allah. Keller menuliskan bahwa kata serupa pada bagian ini memiliki arti kesesuaian secara menyeluruh. ${ }^{28}$ Dalam pendapatnya, Keller sedang menjelaskan bahwa orang percaya tidak boleh memiliki keserupaan baik luar dan dalam

\footnotetext{
${ }^{25}$ Harvey, Romans (Exegetical Guide to the Greek New Testament) 2, 681 .

${ }^{26}$ Wenham, Bahasa Yunani Koine, 54.

${ }^{27}$ William Barclay, Pemahaman Alkitab Setiap Hari-Surat Roma(Jakarta: BPK Gunung Mulia, 1996).

${ }^{28}$ Keller, "Romans 8-16 for You", 180.
} 
dengan dunia. Keserupaan dalam memiliki arti karakter yang tidak terlihat sedangkan keserupaan luar merupakan perilaku hidup sehari-hari. Dengan demikian, setiap orang percaya tidak boleh serupa dengan dunia baik dalam hal karakter maupun perilaku sehari-hari.

Pada bagian berikutnya, Paulus menuliskan dunia sebagai bagian dari larangan kata serupa. Mengapa Paulus menuliskan larangan ini? Ada kemungkinan Paulus mendorong jemaat untuk tidak hidup mengikuti perilaku dunia. Douglass J Moo menuliskan Paulus menuntut pembaca untuk menyesuaikan diri dengan zaman yang ada dan tidak terjebak bujukan atau perilaku dosa yang ada di dunia. ${ }^{29}$ Jika menghubungkan satu frasa ini secara keseluruhan, Paulus sedang mendorong jemaat untuk tidak mengikuti kehidupan dunia sebagai bentuk dari mempersembahkan tubuh kepada Tuhan sebagai persembahan yang hidup. Paulus sedang mendorong jemaat untuk hidup takut akan Tuhan secara keseluruhan baik karakter yang tidak kelihatan maupun perilaku hidup sehari-hari.

Paulus memberikan solusi serupa dengan dunia dengan berubah lewat pembaharuan akal budi. Paulus menggunakan kata berubah dari bahasa

${ }^{29}$ Douglas J.Moo, The NIV Application Commentary: Romans (Grand Rapids Michigan: Zondervan, 2000), 530.
Yunani

$\mu \varepsilon \tau \alpha \mu о \rho \varphi о \tilde{\sigma} \sigma \theta \varepsilon$

(metamorphousthe) yang memiliki arti mengalami perubahan dari bagian sebelumnya. $^{30}$ Perubahan yang dimaksudkan seperti perubahan bentuk. Metamorphosis dapat dilihat dalam siklus kehidupan kupu-kupu yang bermula dari telur-ulat-kepompong kemudian kupukupu. John Stott menuliskan bahwa Paulus memakai kata metamorphosis untuk menyeberangkan perubahan kehidupan orang percaya menjadi serupa dengan Yesus. ${ }^{31}$

Perubahan kehidupan orang percaya menjadi seperti Kristus melalui proses Progressive Sanctification. Dikatakan sebagai proses karena manusia masih hidup di dunia dan memiliki kecenderungan untuk berbuat dosa. Kecenderungan inilah yang menjadi tantangan bagi seseorang untuk memilih hidup dalam dosa atau terus diubahkan menjadi seperti Kristus. Sarumaha menuliskan setiap orang yang sudah dibenarkan harus menyerahkan diri sepenuhnya kepada Allah dan melihat pengudusan sebagai proses dalam mencapai kesempurnaan. ${ }^{32}$

30 Knight, Exploring Romans: Devotional Commentary, 235.

31 John R. W Stoot, Romans: God's Good News For The World (Illinois: InterVarsity, 1994), 502.

32 Nurnilam Sarumaha, "Pengudusan Progresif Orang Percaya Menurut 1 Yohanes 1:9," Kurios: Jurnal Teologi dan Pendidikan Agama Kristen 5, no. 1 (2019): 5. 
Paulus menyinggung perubahan kehidupan orang percaya dilakukan melalui pembaharuan akal budi. Keller menuliskan pembaharuan akal budi merupakan cara untuk melihat kemurahan Allah dalam kehidupan sehari-hari. ${ }^{33} \mathrm{Hal}$ yang sama dituliskan Hagelberg yang menilai bahwa seseorang belum mengalami pembaharuan akal budi maka tidak sanggup membedakan kehendak Allah. ${ }^{34}$ Dari Pendapat Hagelberg dapat dilihat bahwa pembaharuan pikiran merupakan syarat mutlak untuk dapat memahami kehendak Allah. Mengapa demikian? Dengan pikiran yang diperbaharui, seseorang akan menjalani kehidupan berdasarkan perspektif ilahi.

\section{Pelaksanaan Ibadah Daring}

Pandemi covid 19 berdampak pada banyak hal termasuk pelaksanaan ibadah yang semula dilakukan dalam pertemuan fisik berubah menjadi via daring. Situasi ini memaksa setiap orang untuk beradaptasi dengan kebiasaan baru ini. Pada awal mula ibadah daring dilaksanakan, banyak gereja melakukan dengan berbagai macam cara seperti ibadah tatap muka via zoom, skype dan

\footnotetext{
${ }^{33}$ Keller, "Romans 8-16 for You", 111.

${ }^{34}$ Dave Hagelberg, Tafsiran RomaDari Bahasa Yunani (Bandung: Yayasan Kalam Hidup, 2004), 239.
}

google meet serta menonton ibadah via youtube. Berbagai macam upaya dilakukan agar jemaat Tuhan tetap dapat beribadah walau pelaksanaan via daring.

Di dalam pelaksanaan ibadah daring, muncul beberapa kendala seperti: Pertama, banyaknya chanel streaming ibadah. $^{35}$ Meskipun banyak orang yang setia beribadah pada chanel gerejanya masing-masing, melimpahnya channel streaming dapat menjadi godaan untuk pindah channel ketika ibadah yang diikuti membosankan dan tidak menarik.

Kedua, ibadah daring dapat dilakukan bersamaan dengan pekerjaan lain. ${ }^{36}$ Artinya, sambil ibadah daring bersamaan juga dapat sambil makan, mengerjakan pekerjaan rumah tangga dan lainnya. Hal ini tentunya membuat seseorang tidak fokus dalam mengikuti ibadah daring. Walau pada dasarnya konsentrasi seseorang dalam beribadah ditentukan oleh masing-masing.

Ketiga, ibadah daring dapat dimulai dan diakhiri kapan saja. ${ }^{37}$ Setiap channel ibadah daring memiliki waktu masing-masing dan menjadi bisa dilihat

\footnotetext{
35 "Apakah Ibadah Online Di Saat Pandemi Sama Dengan Nonton Khotbah? Halaman 1 - Kompasiana.Com," accessed October 26, 2020, https://www.kompasiana.com/timotiuscong/5eb64 52b097f36681e3e8f34/ibadah-online-dipandemisama-dengan-nonton-khotbah-alasannya. ${ }^{36}$ Ibid.

${ }^{37}$ Ibid.
} 
kapan saja. Hal ini menjadi godaan untuk mengikuti ibadah kapan saja. Artinya, mereka tidak dapat mengikuti ibadah tepat waktu sesuai jadwal seharusnya, justru jadwal ibadah disesuaikan dengan kegiatan yang ada.

Keempat, ibadah daring hampir sama dengan menonton ibadah. ${ }^{38}$ Karena ibadah daring adalah melihat ibadah di media elektronik, muncul kesan bahwa ibadah daring sama dengan menonton ibadah. Hal ini menjadi masalah karena jemaat akan cenderung fokus melihat apa yang ada di dalam ibadah daring daripada berelasi dengan Allah.

Kelima, munculnya iklan dalam ibadah. ${ }^{39}$ Hal yang cukup mengganggu dalam ibadah daring adalah iklan yang muncul di tengah-tengah ibadah. Meskipun iklan tersebut berguna untuk kelangsungan channel ibadah daring, Iklan dapat memecah konsentrasi dalam mengikuti ibadah. Untuk itu, ibadah daring sebaiknya tidak perlu ada iklan di dalamnya supaya fokus dalam mengikuti ibadah dapat tetap terjaga.

Meskipun dalam pelaksanaannya ditemukan banyak kendala, ibadah daring merupakan solusi yang tepat untuk saat ini disamping ibadah pertemuan fisik dengan penerapan social distancing dan

\footnotetext{
${ }^{38}$ Ibid.

39 "Ibadah Online Halaman All Kompasiana.Com," accessed October 26, 2020, https://www.kompasiana.com/pattun65836/5e779 63a097f365fb9652c42/ibadah-online $?$ page $=$ all.
}

physical distancing. Jika demikian, bagaimana cara memaksimalkan pelaksanaan ibadah daring? Bagaimana cara untuk menghilangkan kejenuhan dalam mengikuti ibadah daring dan tetap memiliki relasi dengan Tuhan?

\section{Tinjauan Efektifitas Pelaksanaan \\ Ibadah Daring Berdasarkan Roma}

\section{2:1-2}

Efektifitas pelaksanaan ibadah daring dipengaruhi dari konsep ibadah dari masing-masing orang percaya. Artinya, jika orang percaya memiliki konsep yang benar tentang ibadah maka ibadah daring dapat menolongnya untuk dapat tetap bersekutu dengan Tuhan. Christimoty menuliskan bahwa teologi ibadah mempengaruhi sikap dan cara dalam beribadah. ${ }^{40}$

Ibadah di dalam Roma 12:1-2 lebih berbicara dalam kehidupan seharihari orang percaya yang ditandai dengan adanya perubahan hidup. Jika orang percaya memahami ibadah adalah kehidupan sehari-hari maka ibadah dari hanyalah cara untuk membantu bersekutu dengan Tuhan. Begitu juga dengan kendala dalam ibadah daring tidak mempengaruhi efektifitas dan esensi dari ibadah itu sendiri. Untuk itu jika orang

40 Christimoty, "Teologi Ibadah Dan Kualitas Penyelenggaraaan Ibadah: Sebuah Pengantar": 3. 
percaya dapat memahami ibadah di dalam Roma 12:1-2, maka dapat melakukan ibadah daring dengan tingkat keseriusannya sama seperti ibadah pertemuan fisik.

Bertolak dari tujuan ibadah yang berfokus kepada perubahan hidup, orang percaya harus memahami dan memberi perhatian kepada perubahan hidup daripada masalah teknis dan kendala dalam ibadah daring. Pada dasarnya, orang yang beribadah akan mengalami perubahan hidup semakin lebih baik. Takaliuang menuliskan jika seseorang beribadah namun tidak menunjukkan perubahan karakter maka ia tidak memahami dan melakukan ibadah yang sebenarnya. ${ }^{41}$ Pendapat Takaliuang menunjukkan bahwa intensitas dan pemahaman seseorang dalam beribadah berbanding lurus dengan perubahan hidup. Artinya, perubahan hidup seseorang merupakan muara atau output dari pemahaman dan pelaksanaan ibadah.

Ibadah daring merupakan salah satu cara ibadah yang memungkinkan pada masa pandemi covid 19 di samping ibadah langsung dengan menerapkan social distancing dan physical distancing. Karena itu, ibadah daring memiliki fungsi

\footnotetext{
41 Jammes Juneidy Takaliuang, "Ibadah Sebagai Gaya Hidup Menurut Roma12: 1 Dan Implikasinya Bagi Ibadah Masa Kini” Missio Ecclesiae 2, no. 1 (2013): 82.
}

dan tujuan yang sama seperti ibadah pertemuan fisik yaitu sebagai sarana manusia dalam bersekutu dengan Allah. Dwiraharjo menuliskan bahwa ibadah daring bukanlah merupakan pilihan melainkan keniscayaan. ${ }^{42}$

\section{KESIMPULAN DAN SARAN}

Berdasarkan Roma 12:1-2, ibadah dapat dilihat dari kehidupan sehari-hari yang ditunjukkan adanya perubahan hidup. Perubahan yang dimaksudkan di sini adalah perubahan karakter seseorang menjadi semakin seperti Kristus. Dalam kaitannya dengan efektifitas ibadah daring, pelaksanaan ibadah daring dapat terlaksana maksimal bila seseorang memiliki konsep yang benar tentang ibadah. Selain itu, orang percaya perlu memahami bahwa ibadah daring hanya salah satu cara yang memungkinkan untuk dilakukan dalam situasi pandemic covid 19. Untuk itu, orang percaya harus berfokus kepada tujuan ibadah dan juga melakukan ibadah daring dengan serius seperti ibadah pertemuan fisik. Jika beberapa hal di atas dapat diperhatikan maka efektifitas pelaksanaan ibadah daring dapat tercapai maksimal.

\footnotetext{
${ }^{42}$ Dwiraharjo, "Konstruksi Teologis Gereja Digital: Sebuah Refleksi Biblis Ibadah Daring Di Masa Pandemi Covid-19", 14.
} 


\section{DAFTAR PUSTAKA}

Barclay, William. Pemahaman Alkitab Setiap Hari-Surat Roma. Jakarta: BPK Gunung Mulia, 1996.

Bruce, F F. Romans : Tyndale New Testament Commentaries. Nottingham: Inter-Varsity, 2008.

Christimoty, Debora Nugrahenny. "Teologi Ibadah Dan Kualitas Penyelenggaraaan Ibadah: Sebuah Pengantar." Pasca: Jurnal Teologi dan Pendidikan Agama Kristen 15, no. 1 (2019): 1-7.

Dave Hagelberg. Tafsiran Roma Dari Bahasa Yunani. Bandung: Yayasan Kalam Hidup, 2004.

Dunn, James D.G. Word Biblical Commentary, Volume 38B: Romans 9-16,. Grand Rapids Michigan: Zondervan, 1988.

Dwiraharjo, Susanto. "Konstruksi Teologis Gereja Digital: Sebuah Refleksi Biblis Ibadah Online Di Masa Pandemi Covid-19." EPIGRAPHE: Jurnal Teologi dan Pelayanan Kristiani 4, no. 1 (May 29, 2020): 1. Accessed July 25, 2020. http://dx.doi.org/10.33991/epigraphe .v4i1.145.

Everett F. Harrison, Donald A. Hagner, and Robert K. Rapa. "The Expositor's Bible Commentary: Romans -Galatians. Grand Rapids Michigan: Zondervan, 2008.

Harvey, John D. Romans (Exegetical Guide to the Greek New Testament) 2. Nashvile: B\&H Publishing Group, 2017.

J.Moo, Douglas. The NIV Application Commentary: Romans. Grand Rapids Michigan: Zondervan, 2000.
Keck, Leander. E. Romans: Abindon New Tettament Commentaries. Nashvile: Abingdon Press, 2005.

Keller, Thimothy. "Romans 8-16 for You." Epsom: The Good Book Company, 2014.

Knight, George R. Exploring Romans: Devotional Commentary. Maryland: Review and Herald Publishing, 2010.

Manurung, Arnold. "Makna Frasa 'Ibadahmu Yang Sejati' Menurut Roma 12:1-2." KERUGMA: Jurnal Teologi dan Pendidikan Agama Kristen 1, no. 2 (2019): 90-109.

Marbun, Pardomuan. "Konsep Dosa Dalam Perjanjian Lama Dan Hubungannya Dengan Konsep Perjanjian." CARAKA: Jurnal Teologi Biblika dan Praktika 1, no. 1 (May 7, 2020): 1-16. Accessed July 31, 2020. https://ojs.sttibc.ac.id/index.php/ibc/ article/view/9.

Murray, John. The Epistle to the Romans, Vol 2 Chapters 9 to 16. Grand Rapids Michigan: Williams B. Eerdmans Publshing Company, 2009.

Nida, Johannes E Louw dan Eugene A. Greek English Lexicon of The New Testament. New York: United Bible Societes, 1989.

Peterson, David G. Biblical Theology For Christian Proclamation:

Commentary on Romans. Nashvile: B\&H Publishing Group, 2017.

Sandy, William, Arthur C Headlamp. Romans (International Critical Commentary). Grand Rapids Michigan: Zondervan, 2014.

Sarumaha, Nurnilam. "Pengudusan Progresif Orang Percaya Menurut 1 Yohanes 1:9." Kurios: Jurnal Teologi dan Pendidikan Agama Kristen 5, no. 1 (2019): 1-11. 
Siringo-ringo, Elfrida. "Pemahaman Ibadah Sejati Berdasarkan Roma 12:1-2 Terhadap Pertumbuhan Kerohanian Remaja GPPS Maranata Diski: Studi Eskesegetis." PROVEDENSI : Jurnal Pendidikan dan Teologi 1, no. 1 (2018): 27-51.

Stoot, John R. W. Romans: God's Good News For The World. Illinois: InterVarsity, 1994.

Takaliuang, Jammes Juneidy. "IBADAH SEBAGAI GAYA HIDUP MENURUT ROMA 12: 1 DAN IMPLIKASINYA BAGI IBADAH MASA KINI." Missio Ecclesiae 2, no. 1 (2013): 61-84.

Wenham, J W. Bahasa Yunani Koine. Malang: SAAT, 1987.

"Apakah Ibadah Online Di Saat Pandemi Sama Dengan Nonton Khotbah? Halaman 1 - Kompasiana.Com.” Accessed October 26, 2020. https://www.kompasiana.com/timoti uscong/5eb6452b097f36681e3e8f34 /ibadah-online-dipandemi-samadengan-nonton-khotbah-alasannya.

"Ibadah Online Halaman All Kompasiana.Com." Accessed October 26, 2020. https://www.kompasiana.com/pattun 65836/5e77963a097f365fb9652c42/ ibadah-online?page=all.

"Jokowi: Saatnya Kerja Dari Rumah, Belajar Dari Rumah, Ibadah Di Rumah Halaman 2 - Kompas.Com." Accessed July 26, 2020. https://nasional.kopmpas.com/read/2 020/03/15/14232961/jokowisaatnya-kerja-dari-rumah-belajardari-rumah-ibadah-dirumah?page $=2$.

"PGI Dukung Ibadah Online Untuk Mengatasi Penyebaran Covid-19Website PGI." Accessed July 27, 2020. https://pgi.or.id/pgi-dukungibadah-online-untuk-mengatasipenyebaran-covid-19/.

"PRO-KONTRA IBADAH ONLINE Bahana Online.” Accessed July 27, 2020. http://ebahana.com/ 
